\title{
The Effects of Hevea Bransiliensis Natural Rubber on Liver Total and Free Cholesterol Concentration of Experimental Rats
}

\author{
${ }^{1}$ Bawa Abubakar, ${ }^{2}$ Njoku O. U., ${ }^{3}$ Salihu Suleiman, ${ }^{2}$ Ozougwu V.E.O., \\ ${ }^{2}$ Agu Chidozie V.And ${ }^{2}$ Okonkwo C. C. \\ ${ }^{I}$ Department Of Preliminary And Remedial Studies, Federal Polytechnic Mubi, Adamawa State, Nigeria. \\ ${ }^{2}$ Department Of Biochemistry, University Of Nigeria, Nsukka, Enugu State Nigeria. \\ ${ }^{3}$ Department Of Chemistry, Federal University Dutse, Jigawa State, Nigeria.
}

\begin{abstract}
The effects of various Hevea brasiliensis (refined rubber seed oil) incorporated diets on wister albino rats were assayed. The results showed a general increase in total and free cholesterol levels of the rats within the duration of feeding. It was, however, observed that the increase in liver total cholesterol level was greater in groups $E$ rats fed with (4\% crude rubber seed oil incorporated diet) compared to groups $C, B$ and $D$ rats for the each of the corresponding weeks. It was also observed that the increase in liver free cholesterol level was greater in group $E$ rats fed with (4\% crude rubber seed oil incorporated diet) than groups A (control), B, C and $D$ rats for each of the corresponding weeks.
\end{abstract}

Keywords: Hevea brasiliensis, Wister rats, Seed oil, Cholesterol and Diets.

\section{Introduction}

Fats and other lipids are essential for the normal functioning of the tissues and organs, as well as of the whole body [1]. Thus, in the master tissue of the body, namely the brain, as well as in the spinal cord and associated nervous system, phospholipids, cholesterol and galactolipids form a large part of the essential portion of the functioning tissue [2]. The lipids are part of the structural elements and these cells could not function without them [2]. Moreover, all cell membranes throughout the body apparently contain lecithin, a phospholipid which is derived from fat. One of the effects of prolonged fat deficiency in rats is the failure of normal kidney functions; this is in all probability to be ascribed to the failure of the body to build up normal cell membranes [3]. Fats also serve as a mechanical protection for nerves and for bony projections. The layer of subcutaneous fat is undoubtedly of considerable importance in maintaining body temperature, particularly because of its function as an insulator. Adipose tissue, in addition to connective tissue, acts as a protective covering for organs such as kidney and ovaries, which are frequently imbedded in large amounts of storage fat.

Cholesterol is the main sterol of animal tissues and consequently, foods that are derived from animal products contain cholesterol. It is always found in vertebrates and in some invertebrates but not in plants. In plants it is replaced by $\beta$ - sitosterol [ 3 and 4]. The distribution of cholesterol between tissues and body fluids depend on the degree of saturation of the serum fatty acids. Saturated fatty acids in the diet increase plasma cholesterol [5].

The primary polyunsaturated fatty acids undoubtedly are linoleic and arachidonic acids, although linolenic acid and certain other related compounds can also serve in the same capacity probably because of the ability of the animal body to convert them to one of the primary types. These 'essential' fatty acids are known to be required for growth and for the maintenance of normal skin conditions by a wide variety of animals and by man. More recently it has been shown that the essential fatty acids mediate not only growth but also certain diverse functions such as protection from $\mathrm{X}$ - irradiation injury, maintenance of capillary resistance in the skin capillaries, and the normal transport and metabolism of cholesterol [6].

Natural rubber, (Hevea brasiliensis and Fantumia elastica) are two species of the rubber tree found in the humid belt of the tropics [7]. The latter species appears to have a more restricted geographic distribution to the lowland rainforest belt of West Africa, whereas Hevea brasiliensis extends in the humid tropical belt from Brazil in the West, through West and Central Africa to India, Malaysia and Indonesia in the East [8].

In view of the abundant Natural rubber plantation in Eastern and Western states of Nigeria, it has necessitated various researches to be carried out all aimed at investigating thoroughly the nutritional potentials of rubber seed in form of cake and oil.

\section{Meterial And Methods}

Forty (40) albino wister rats of either sex weighing $140-450 \mathrm{~g}$ were used for this analysis. The rats were obtained from the animal house of National Institute of Trypanosomonas Research Centre, Vom in Plateau State, Nigeria. They were kept in stainless steel cages with raised wire floors in a room maintained at $37^{\circ} \mathrm{C}$. The animals were fed for a period of 12 weeks. The rats were divided into five equal groups marked A, B, C, D and 
$\mathrm{E}$ of eight rats each, and each group was fed on different dietary regime A, B, C, D and E respectively as indicated in tables 1 and 2. Diet A, (the control) has no rubber seed oil in the diet, whereas diets B, C, D and E (the experimental) had $2 \%$ refined rubber seed oil, $2 \%$ crude rubber seed oil, $4 \%$ refined rubber seed oil and $4 \%$ crude rubber seed oil by weight incorporated respectively.

The rats were initially starved for $24 \mathrm{~h}$ before being fed adlibitum with the various diets. Measurement of the liver cholesterol levels were carried out at the beginning of the experiment and subsequently at the end of every four weeks throughout the period of experiment, except the histochemical investigation of the liver that was done initially at the end of three months.

Table 1: Feeding patterns with rubber seed oil incorporated diet

(Njoku, O.U. and Ononogbu, I.C., 1996).

\begin{tabular}{|l|l|l|l|l|l|}
\hline $\begin{array}{l}\text { Group/Treatment of } \\
\text { Rations \% }\end{array}$ & A & B & C & D & E \\
\hline Maize flour & 70 & 68 & 68 & 66 & 66 \\
\hline Fish meal & 10 & 10 & 10 & 10 & 10 \\
\hline Groundnut cake & 20 & 20 & 20 & 20 & 20 \\
\hline Ruber seed oil & - & 2 & 2 & 4 & 4 \\
\hline
\end{tabular}

Table 2: Components of rat feed/100g edible portion modified by (Njoku, O.U. and Ononogbu, I.C., 1996).

\begin{tabular}{|l|l|l|l|l|l|l|l|}
\hline & Water $(\mathrm{ml})$ & Protein $(\mathrm{gm})$ & Fat $(\mathrm{gm})$ & $\begin{array}{l}\text { Carbohydrate } \\
(\mathrm{gm})\end{array}$ & Fibre (gm) & Mineral (gm) & Vitamin (gm) \\
\hline Maize flour & 12 & 10 & 4.5 & 71 & 2.0 & 14.5 & 2.48 \\
\hline $\begin{array}{l}\text { Groundnut } \\
\text { cake }\end{array}$ & 6 & 27 & 45 & 17 & 3.0 & 52.5 & 18.05 \\
\hline Fish meal & 20 & 63 & 6.3 & - & - & 3008 & 6.3 \\
\hline $\begin{array}{l}\text { Rubber seed } \\
\text { oil }\end{array}$ & 3.98 & 22.30 & 42.6 & - & 4.20 & 2.9 & - \\
\hline
\end{tabular}

\section{LIVER TOTAL AND FREE CHOLESTEROL DETERMINATION}

The liver was equally excised, placed in a small pre-weighed beaker. The liver was homogenized in phosphate buffer $\mathrm{pH} 6.2$ and the lipid was recollected using chloroform - acetone mixture. The liver cholesterol concentration was determined as in the plasma cholesterol via using the homogenate.

To each test-tube containing $0.2 \mathrm{ml}$ of plasma, $1.8 \mathrm{ml}$ of acetone - ethanol solution was added and centrifuged at 3000rpm for 15 minutes. About $0.4 \mathrm{ml}$ of the clear aliquot was removed and $3 \mathrm{ml}$ of $\mathrm{FeSO}_{4}$ - acetic acid reagent was added and the mixture was allowed to stand for 10 minutes. The absorbance was read on the spectrophotometer at 490nm against a reagent blank.

Table 3: Mean liver total cholesterol concentration (mg/100ml)

\begin{tabular}{|l|l|l|l|l|l|}
\hline \multicolumn{1}{|l|}{ Groups } & B & C & D & E \\
\hline Weeks & A & B & $40.0 \pm 1.50$ & $43.0 \pm 2.00$ & $42.0 \pm 3.00$ \\
\hline 0 & $43.5 \pm 2.50$ & $42.5 \pm 2.00$ & $72.5 \pm 2.50$ & $62.5 \pm 2.50$ & $74.0 \pm 4.00$ \\
\hline 4 & $74.0 \pm 4.00$ & $67.5 \pm 2.50$ & $55.0 \pm 5.00$ & $63.0 \pm 3.00$ & $65.0 \pm 1.50$ \\
\hline 8 & $62.5 \pm 2.50$ & $63.0 \pm 3.00$ & $40.0 \pm 10.00$ & $50.0 \pm 1.50$ & $57.5 \pm 2.50$ \\
\hline 12 & $45.0 \pm 5.00$ & $45.0 \pm 5.00$ & &
\end{tabular}

Table 4: Mean liver free cholesterol concentration (mg/100ml)

\begin{tabular}{|l|l|l|l|l|l|}
\hline & Groups & D & E \\
\hline Weeks & A & B & C & D & $42.0 \pm 2.00$ \\
\hline 0 & $42.0 \pm 3.00$ & $39.5 \pm 1.00$ & $35.0 \pm 2.50$ & $40.0 \pm 0.50$ & $43.0 \pm 2.50$ \\
\hline 4 & $52.0 \pm 1.00$ & $50.0 \pm 2.00$ & $45.5 \pm 1.50$ & $38.0 \pm 2.00$ & $59.0 \pm 1.00$ \\
\hline 8 & $49.5 \pm 2.50$ & $42.0 \pm 2.00$ & $36.0 \pm 0.50$ & $44.0 \pm 4.00$ & $49.5 \pm 2.50$ \\
\hline 12 & $42.0 \pm 2.00$ & $40.0 \pm 0.60$ & $33.5 \pm 0.50$ & $47.0 \pm 1.00$ \\
\hline
\end{tabular}

\section{Results And Discussion}

Cholesterol levels in the liver of the rats were analyzed in the course of the research and the values of mean liver total cholesterol level shown in Table 3 for the corresponding weeks. The results showed a general increase in total cholesterol level within the duration of feeding. It was, however, observed that the increase in liver total cholesterol level was greater in groups E (4\% crude rubber seed oil incorporated diet) and A (control) than groups C, B and D for the corresponding weeks. Groups B and D animals, on the other hand, showed a minimal increase in liver total cholesterol level within the duration of feeding as shown in (Table 3). It may be due to the various levels of refined rubber seed oil incorporated diets that is 2 and $4 \%$ respectively. Also mean liver free cholesterol level was determined during the course of the research (Table 4). The results generally 
showed an increase in liver free cholesterol level during eight weeks of the experiment and falls in the last four weeks of feeding of the animals in all the groups.

It was observed that the increased in liver free cholesterol level was greater in group E (4\% crude rubber seed oil incorporated diet) than groups A (control), B, C and D for the corresponding weeks. Group D animals showed very little increase in mean liver cholesterol level in the course of the experiment (Table 4).

\section{Conclusion}

In conclusion, various levels of refined rubber seed oil incorporated diets (Hevea brasiliensis) could be capable of elevating total and free liver cholesterol of wister albino rats.

\section{References}

[1]. Abumrad, N.A., Stearns, S.B., Tepperman, H.M. and Tepperman, J.J. Lipid Res. 19, 423-432 (1978). In: The Lipid Composition of Adipose Tissue in Pro. Lipid Res. Vol. 27. Pp. 39-60. (1988)

[2]. Ackman, R.G. (1991). Oxidation Susceptibility of Encapsulated Fish Oil Products: A Comparison of triglycerides versus free acids. JAOCS 66, 966-969.

[3]. Adams, A., A.M.A. Durand, and D.D. Taylor (1964). Serum cholesterol concentration and atherosclerosis cardiovascular disease in the aged. Fed. Proc. 23; 823.

[4]. Ahrens, E.H., J. Hiesch, M.L. Peterson and W. Stoffel (1957). The influence of dietary fats on serum lipid levels in man. Lancet. I, 943.

[5]. Aigbodion, A.I. and Pillai, C.K.S. (2000). Preparation Analysis and Application of Rubber Seed Oil and its Derivatives in Surface Waitings. Progress in Organic Coating's 38. Pp. 187-192.

[6]. Angus, M.G.N., K.A. Fletcher and B.G. Malgraith (1971a). Studies on the lipids of plasmodium knowlesi-infected rhesus monkeys (Macaca mulatta) 1: Changes in serum lipids. Ann. Trop. Med. Parasitol., 65; 135.

[7]. Ansell, Gb. And J.N. Hawthorne (eds.). Phospholipids: Chemistry, metabolism and function. Elsevier pub. Coy., Amsterdam, Lond. New York. (1964)

[8]. B.T. Sacheer; E. Straub, M. Fields; E.R. Meserve, C. Hendrick, and H.J. Drel Jr. J. Nutrition; 34, 581-586 (1947).

[9]. Njoku, O.U. and Ononogbu, I.C. (1996). Toxicology Studies of the rubber (Hevea brasiliensis) seed oil. West African J. Biol.Sc. 4(2): $135-140$ 